\title{
A Historical View of Human Resource Management Practice: Literature Review
}

\author{
Hassan Danial Aslam \\ Lecturer, Faculty of Management Sciences, The Islamia University of Bahawalpur (Pakistan) \\ Email: hassan.danial@hrmars.com \\ (Corresponding Author) \\ Mehmood Aslam \\ MS Scholar, Faculty of Management Sciences, The Islamia University of Bahawalpur \\ (Pakistan) \\ Naeem Ali \\ Visiting Faculty, Faculty of Management Sciences, The Islamia University of Bahawalpur \\ (Pakistan) \\ Badar Habib \\ Lecturer, Department of Physical Education, The Islamia University of Bahawalpur \\ (Pakistan) \\ Madiha Jabeen \\ MS Scholar, Faculty of Management Sciences, The Islamia University of Bahawalpur \\ (Pakistan) \\ Doi:10.5296/ijhrs.v3i2.6254 URL: http://dx.doi.org/10.5296/ijhrs.v3i2.6254
}

\begin{abstract}
Managing human resource has always remained as an important concern for managers. At present, human resource management is being seen as a main stream department in modern businesses. This paper attempts to focus on history of this management function. This theoretical research narrows down the literature and presents a detailed analysis of the origins of human resource management discipline. Author has elaborated various researches and literature resources in order to comprehend the history of human resource management theories and focus on various theories, models and frameworks on which this discipline was started off in the past.
\end{abstract}

\section{Introduction}

Human Resource Management is usually considered the major and significant element of successful organizations. To attain and sustain the competitive advantage, it occupies more 
importance than technology and finance. Specifically, it is important in the services sector where employees are the main source of contact with customers, whether it is a face-to-face meeting or its telephone or over the internet service encounter. In HRM, employees' skills are developed to provide better quality products and services. In this context, "High Commitment Model" is envisioned as a specific approach in human resource management.

According to Drucker (1997) "it is not technology, but the art of human and humane-management" which executives of $21^{\text {st }}$ century see as a growing challenge." Likewise, Smith and Kelly (1997) mentioned that "future economic and strategic advantage will be with the organizations that can most effectively attract, develop and retain a diverse group of the best and the talented people in the market place".

Generally, in order to attain the targeted profitability and survival results, and to keep up the competitive advantage, firms are responsible to manage the resources accordingly. There are three resource categories available to the firm including physical, organizational and human resources. In his discussion about gaining competitive advantage in global arena, Porter (1990) mentioned that most critical of all the activities is managing the human resource. But many authors have criticized a lot the belief of taking human resources as a way to gain competitive advantage in domestic and international marketplaces.

Opposing to this, Greer (1995) emphasized the importance of human resource as a source of gaining competitive edge for the organizations. It is strongly perceived that highly developed skills set of employees, unique organizational culture and management procedures and systems can result in distinctive competencies for the organization, as opposed to traditional importance given to movable resources e.g. equipment. Also, it is highly acknowledged that high quality workforce help the organization achieve the competitive advantage based on their market responsive behavior, high quality products and services, unique in products and technological innovations for better performance.

Thus all that transcribes that if an organization really want to perform outstandingly well and aspire to hold a strong footing in the market it truly have to manage its workforce effectively in the sense that they have to develop them keeping in mind the best practices of HRM. This would become possible if this is also recognized by everyone in an organization irrespective of the cadre of employee who is involved in. Again, if a strong pro-employee culture takes a birth, this would definitely work for the betterment of the entire organization in terms of excellent provision of product and/or services to the customers and thereto making the financial position ever stronger in the industry.

\section{Origin of HRM}

With the changing trends of industry in the competition oriented environment of open markets, human resource management becomes a significant variable for the efficient growth of any organization. Manpower planning was the very first concept used in ancient eras and as the time went on the trends changed dramatically and the concept of manpower planning changed 
and turned into personal management. Today personal management is known as Human resource management.

Some of the factors or significant variables mentioned by the American writers, Terrey and Franklin (1996), termed as six "M" of management including men, material, women, money, method and market. Out of all these, the productive management and deployment of these human and non-human resources is done by the living beings, men and women.

Managing human resource is a meticulous process and complex one also. According to Harzing and Ruysseveldt "A better way to understand the philosophy of human resource management demands a thorough understanding about the evolution of the concept itself from the ancestral concept of personnel management".

\section{The Glided Era:}

Historian Page Smith examines the industrial revolution "The War between Capital and Labor." It is stated that both labor and capital sides were indulged in war, with armed people fighting from both sides. The situation created was almost war like because of the extreme human violence and property destruction because most of the workers were civil war experts. They announced that they are ready to shoot any hiring just the way they were willing to kill Yankees or rebels. American industry captains used to view employees as raw material commodities and not humans although those captains faced difficult circumstances in their past. They hired the army personnel to deal with their labor power during all this without even caring for results of their cold and ruthless behavior.

\section{Post-World War II (1945-1960)}

In the days of war, labor movement and utilization put much influence on the enhancement of employee functions. The effectiveness of firm is greatly influenced by employee productivity and inspiration. After the war ended, the unions and associations for hum relations emphasized that employee motivation should be increased by using in addition to money, some social and psychological factors for instance, acknowledging their work, appraising their work standards. At the time of war individuals were categorized in military services, therefore systemized efforts were done to make employees work groups to provide better recruitment and selection measures and opportunities. The deepest parts of the classification included job descriptions containing details of tasks, duties, and responsibilities answering the job seekers' questions. Appropriate compensation systems, appraisal systems were developed using these job descriptions and plans were executed.

\section{Social Issues Era (1963-1980)}

This time span observed an extraordinary increase of performing and accomplishing labor legislation in the United States, legislation that control different parts of the employment association, including the excluding prejudiced practices, provision of retirement settlement, 
the encouragement of work-related issues like health and safety, tax regulation, etc. As an end result, the department of human resources was filled with the extra accountability of legislative fulfillment that comprised of collecting, analyzing, and reporting huge data to legislative units. For example, in terms of making everything transparent, there was no favoritism in employment practices, the human resources department needed to attentively collect, evaluate, and keep data regarding all employment functions, such as recruitment, compensation, training, and benefits. It was that time when personnel department were started to be called human resource management departments. This is how HRM department came into being.

Another contributory factor was the economic prosperity that took place in almost all industrialized countries. Employee trade unions were doing fruitful negotiations for superior working conditions, such as health care and departure settlement. As a result, labor costs rose up than ever before, which forced human resources managers to validate increase in cost against productivity. The HR function has evolved to be protecting one from being caretaker with an increased importance of employee involvement and empowerment, and it changed the focus from maintaining employees to brining betterment for employees.

Therefore, the depth and width of HRM functions extended and thus, brought about the need for planned thinking and superior transfer of HR services.

\section{Cost-Effectiveness Era (1980 to the Early 1990s)}

United States and other international firms had given better attention on reducing costs by deploying automation and other efficiency enhancement procedures, since competition got fierce from the side of European and Asian economies. Moreover, there was an increasing insight within administration because their relative costs were being considered a crucial element of the total budget of company. Fewer companies have calculated their cost of human resource management to be as high as $80 \%$ of their total operating cost.

\section{Era of Technological Advancement and Advent of Strategic HRM (1990 to Present)}

Throughout 1990s, economic background has undergone various drastic changes like increase in the pace of globalization, high-tech progression especially Internet, Web services, and hectic rivalry.

Firms today have realized that pioneering and resourceful employees offer a sustainable viable benefit because, contrasting to other assets, intellectual capital is complex for competitors to reproduce. For that reason, the human resource management function has gained strategic level importance and viewpoint emphasized on to attract, preserve, and hold talented employees. "These developments have been directed to the formation of the HR balanced scorecard (Becker, Huselid, \& Ulrich, 2001; Huselid, Becker, \& Beatty, 2005), in addition to put stress on the return on investment of the HR function and its plan" (Cascio, 
2000; Fitz-enz, 2000, 2002). The greater utilization of technology has altered the meaning and focus HRM, and shifted it to adding the value to the organization's products or services, that turned HR department into the strategic partner of business. "Strategic HRM originate its theoretical impact from the resources-based analysis of the firm that delights human resources as a strategic asset and a competitive advantage in improving organizational performance" (Becker \& Huselid, 2006).

\section{Origin of HRM}

\begin{tabular}{|l|l|l|l|}
\hline Decade & Business Realities & HR Name Changes & Issues \\
\hline Pre-1900 & Small Business \& Guilds & Did not yet even exist & Owners owned the HR issues \\
\hline 1900 & Industrial Revolution & Labor Relations & People as interchangeable parts \\
\hline 1920 & Civil Service \& WWI & Industrial Relations & Workers' rights and more formalized processes \\
\hline 1940 & Scientific Management \& WWII & Personnel Administration & $\begin{array}{l}\text { Efficiency experts and more highly evolved HR } \\
\text { processes }\end{array}$ \\
\hline 1960 & Civil Rights \& Compliance & Personnel & Legal compliance and reporting; "policy police" \\
\hline 2000 & $\begin{array}{l}\text { Service Economy, and Mergers \& } \\
\text { Acquisitions }\end{array}$ & $\begin{array}{l}\text { Human Resources } \\
\text { People }\end{array}$ & $\begin{array}{l}\text { Relevance in a fast-changing world; motivation and } \\
\text { "human relations" theories abound }\end{array}$ \\
\hline & Modern Organizations & $\begin{array}{l}\text { Organization Effectiveness? } \\
\text { Human Capital? } \\
\text { Organizational Capability? }\end{array}$ & $\begin{array}{l}\text { No new official names, but lots of "morphing" } \\
\text { as the transactional parts get outsourced and the }\end{array}$ \\
\hline
\end{tabular}

Source: (Developing HR as an internal consulting organization, Richard M. Vosburgh, Mirage Resorts, MGM MIRAGE)

\section{Mile Stones of HRM:}

The ups and downs of the economic situations in the previous decade had given greater importance to HR and the way it supports the overall business. In the down times of economy, the HR priorities did not favour to have the right talent but these mainly focused on cost reduction and efficiency improvement techniques.

\section{Mile stones of HRM:}




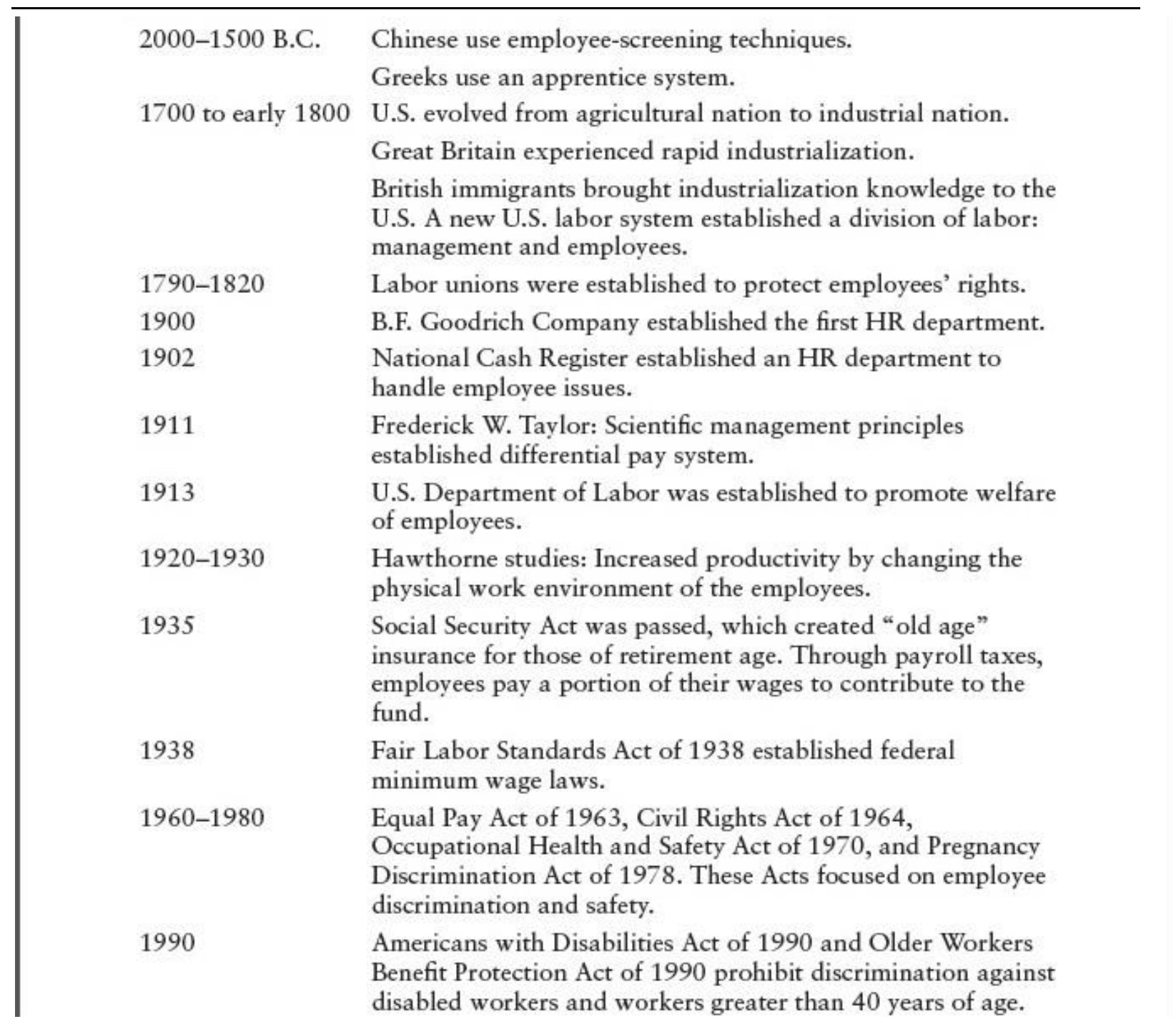

\section{Source: (Jones and Bartlett Learning, Chapter\#1, 2009)}

\section{Role of Human Resource Management in the Organization}

HRM owns a significant role in promising employee satisfaction, and resulting in improved performance and productivity of employees. When any company envisions the business the top wish is to have a competent work force pool, and placing the right person on the right job. Afterwards, the talented set of employees uses other tangible and intangible resources and works on taking decision when, where and from whom the resources should be obtained. The knowledge and art of a manager makes him a man that holds the whole business and organization. Therith (2009) stated that HRM is crucial for companies to gain competitive advantage. Author explained following are the three challenges related to competitiveness:

\section{Challenge of sustainability:}

There are various forms of firms or organizations across the globe which operate at different levels and seem to be implementing strategies which could not only improve 
their human resources but also make them come by competitive advantage. However, sustainability is the one thing that is needed to grow further in terms of reaching to organizational goals. Organization utilize various approaches that help them achieve their goals:

- Learning organization

- Balanced score card

- Total quality management

\section{Global challenge:}

For the survival organizations have to cooperate with each other. Those have to struggle hard to defend themselves in the local market and to reach the global goal. Those even have to communicate with each other and to compete with the foreign organizations.

\section{The technology challenge:}

A change is fundamental skills requirement happens because of technological change, and work roles and usually results in collecting the job tasks together and that is how it becomes challenging for an organization while at times of making strategic plans right in time and in cost effective measures

HRM plays vital role in the organization and it includes different activities. Farndale and Truss (2005), listed some of the major roles HRM assumes in the organization as under:

- Managing employees and their compensation.

- To create positive environment.

- To assist in generating applicant's pool and recruitment process.

- To help in evaluating employees' performance and getting them ready for upcoming task.

- To help in creating pay systems and rewards for the employees.

According to Therith (2009), mentioned below is the new role of the HRM in the institute:

\section{(i). Change through Leader}

In order to achieve already defined goals and gaining competitive edge over competitors, leaders need to play a huge role. They are required to support, facilitate and drive the changes to bring innovations, enhance productivity and improve work quality. 


\section{(ii). Human Resources Strategist}

Achievement of strategic objectives and goals of organization is possible by associating and integrating the HR activities with the strategies. Human resource strategists look ahead and plan HR development activities which enable and ensure good performance resulting in goals achievement.

\section{(iii). Business Strategist}

Under this role, an integration and participation in corporate strategy formulation process is done to cope up with the challenges organization is facing and to give the long lasting competitive edge. Organizational success is the result of well managed process of strategy formulation. This success is multi-faceted encompassing satisfied customers, provision of quality products, and customer services.

\section{(iv). Alignment of Human Resources Function}

The integration of HRM in company's strategic process is mandatory for success of company. Input from HR managers is necessary while make corporate strategies. The input should be about both organization and people related issues. Programs ensuring presences of specific skills, behaviors and attitudes are developed in this regard.

\section{(v). Partner to General Manager}

For survival and success, and for organization to walk on the road of success, HR owns a very important role in one way or the other. HR has a close relation with line manager while making strategic plans, implementing the plans, and work designs. Line managers help HRM to manage and control employees' present performance, increments, promotions and a need of more training, etc.

\section{HRM Practices}

For crafting sound HRM system, the organization should develop and practice effective human resource management practices. According to Schuler and Jackson (1987), Schuler and MacMillan (1984), Wright and Snell (1991), the organizational activities to produce a pool of human talent to ensure that the resources are utilized for the fulfillment of organizational goals are knowns as HRM practices.

\section{Types of HRM Practices}

HR practices are an old concept and many researches through number of decades have been doing a lot on HRM practices and various practices and varying names are identified in 
different researches. As Pankaj Tiwari (2012) cited in Kok Jan de et al. (2003), researchers variably referred to certain sets of HRM practices as "best practice," or "high-performance" (Huselid, 1995), some practices as "formal" (Aldrich \& Langton, 1997; de Kok \& Uhlaner, 2001; Heneman \& Berkley, 1999), some as "sophisticated" (Golhar and Deshpande, 1997; Hornsby \& Kuratko, 1990; Goss et al., 1994; Wagner, 1998) or as "professional" (Gnan \& Songini, 2003; Matlay, 1999). Pfeffer (1994; 1998), argued that the most suitable term is "Best HRM Practices".

As Chandler and McEvoy (2000) stated, there does not exist a 'universally superior approach' encompassing a single set of practices of HRM. There are some HR practices which are of universal nature or may be used alone or combined with other practices.

According to Boxall (1996), Lowe and Oliver (1991), and Pfeffer (1994), it is concluded that to get higher productivity results, profit gains and lowered costs, employees should be well paid, highly motivated and should work in environment of mutualism and trust.

Pfeffer (1994) recognized 16 practices denoted as best practices. Later on, they were changed to seven best practices:

- Job security

- Specific hiring

- Self-administered teams/team working

- High compensation dependent on organizational performance

- Wide-range training

- Reduced status difference

- Information sharing

Redman and Matthews (1998) found out some HRM practices known as 'HRM bundle' to provide support to service organizations' quality strategies, as mentioned below:

- Conducting cautious recruitment and selection process, for example, 'total quality recruitment', 'zero defects recruitment', 'right first time recruitment'.

- Widespread compensation systems should be in practice, for example, staff member with multiple skills should be awarded bonuses.

- Designing team work activities and offering flexible job design, for example, appreciating a sense of integration and co-operation and designing authorized jobs.

- Providing training and learning opportunities, which will result in enhanced interpersonal and social skills of front line staff

- Employee participation, for instance, keeping staff intimated with major and important changes in the organization.

- Periodic performance appraisals linking with reward systems, for example, collecting feedback form customer feedback to evaluate employee performance and their duties that may result in award of bonus for staff. 


\section{Macrothink \\ International Journal of Human Resource Studies \\ ISSN 2162-3058 \\ 2013, Vol. 3, No. 2}

\section{Traditional shortfalls of Human Resource Management}

Many business managers are disturbed with the establishment of HR activities if still these activities are implemented in fine and sound manner as managers are not sure how these practices are helpful in order to developing their employees in effective manner. One of the leaders said "I can realize the importance of HR activities that are related to training, management and development but I am also concerned about which abilities and capabilities are most essential rather than tactical actions". Boudreau and Ramstad (2004) stated that HR managers can devote their more time on HR measurements techniques e.g., HR financial reporting, HR scorecards and even more focus on how can attitudes, skills, abilities and knowledge of employees can be increased to a certain level and to bring effectiveness through HR programs like training and development. However all these HR actions can influence some important decisions of business for example entrance and exit into a new market, etc. These actions can give some ways that how organizations can achieve competitive advantage through effective and more skilled labor. So here the question arises whether business investments and decisions are really measured by talent? Human resource training becomes effective only if it produces desired outcomes and profits.

According to Marchington and Wilkinson (1997), many line managers do not pay any attention to give any priority to HR activities because they already possess much workload and suffer from overload because of inappropriate work allocation from the top management.

Authors advised that with a focus on the training, development, better management of their staff, mentioned in the mission statement of the firm can make line managers change the sequence of priorities as signaled by the top management, thus they will pay attention to attaining the targets which are more assessable and valued as compared to HRM related actions.

The other important issue which is measured as a traditional shortfalls of HRM is the skills progression of the line managers. According to Boyle (1995, p.43), line managers should be ready to play people management role of their job in case if devolution of tasks happens. Many researches indicate that the training, development, management of people and developing them in a proper manner is a critical success factor for any organization (McGovern et al., 1997). Adding to this, Boyle (1995) opined that it is a challenge to develop such skills in the public sector, where managers may perceive themselves as specialists, instead of being managers. Similarly, managers also need practical and professional support from the top management and to obtain skills that they need to assume responsibilities for HRM activities (Merchant and Wilson, 1994).

\section{a. New origin}

HRM is a modern source and through human resource activities organizations can achieve competitive advantage however different views or concepts are coming from different authors about HRM. Some proclaim that it is personnel management and some say that it is 


\section{Macrothink

traditional personnel management.

\section{b. Absence of top management support}

HRM needs the support from top management of firm that can modify the attitude and can bring fine result at times of implementing human resource processes and policies. Because of inappropriate attitude of the top management level, the work is maintained by people of personnel management department.

\section{c. Inappropriate implementation}

Bringing employees' training and development needs is a way of implementing human resource management policies and processes. HR policies and practices should be designed in accordance with the needs and aspirations of people working in the company. Organization cannot achieve predetermined results without proper implementation of human resource activities and programs.

\section{d. Insufficient development programs}

Human resource management involves implementations of programs for example career planning like provision of career guidance as how employees can make their career choices, on the job training that how employees perform their current job more efficiently, development of programs that are useful in their future job tasks, counseling, etc.

\section{e. Insufficient information}

Some organizations are unable to have proper information about their employees and that is how the data base system does not properly implement. Well before implementing the process of human resource management, essential data about training and development, rightly according to the needs of the employees, should be collected and stored. 


\section{References}

1. Kaizenlog, (2006). The historical background of human resource management.

2. Salvatore, P., Weitzman, A., \& Halem, D. (2005). How the Law Changed HR. HR Magazine, 13, 50, 47-56.

3. Senyucel, Ventus. (2009). Managing the Human resource in $21^{\text {st }}$ century. ApS ISBN (978-87-7681-468-7).

4. Smith, A People's History of the Post-Reconstruction Era: The Rise of Industrial America, New York, 1984, p. xiii.

5. Vosburgh, R. M. and Resorts,M. Developing HR as an internal consulting organization. Human resource planning, 30.0.

6. Becker, B. E., Huselid, M. A., \& Ulrich, D. (2001). The HR scorecard: Linking people, strategy, and performance. Boston: Harvard Business School Press.

7. Beatty, R. W., Huselid, M. A., \& Schneier, C. E. (2005). New HR metrics: Scoring on the business scorecard. Organizational Dynamics, 32(2), 107-121.

8. Becker, B. E., \& Huselid, M. A. (2006). Strategic human resource management: Where do we go from here? Journal of Management, 32(6), 898-925.

9. Cascio, W. F. (2000). Costing human resources: The financial impact of behavior in organizations (4th Ed.). Cincinnati, OH: South-Western College.

10. Fitz-enz, J. (2000). The ROI of human capital: Measuring the economic value of employee.

11. Performance. New York: AMACOM/American Management Association.

12. Fitz-enz, J. (2002). How to measure human resource management (3rd ed.). New York: McGraw-Hill.

13. Boudreau, J.W. \& Ramstad, P.M. (2004). Talentship and the Evolution of Human Resource Management From "Professional Practices" To "Strategic Talent Decision Science". 